\title{
Studi Defomasi Perkerasan Kaku dengan Bahan Tambah Kimia dan Pengaruh Elevated Temperature
}

\author{
Emil Adly $^{\mathrm{a} *}$, Iswatul Fatimah ${ }^{\mathrm{b}}$ \\ ${ }^{a}$ Program Studi Teknik Sipil, Fakultas Teknik, Universitas Muhammadiyah Yogyakarta \\ ${ }^{b} \mathrm{CV}$. Atmo Podo, Jepara, Jawa Tengah
}

Riwayat Artikel

Diserahkan

1 Desember 2020

Direvisi

4 Januari 2021

Diterima

1 Februari 2021

${ }^{*}$ Penulis korespondensi emil.adly@umy.ac.id

\begin{abstract}
Abstrak
Perkerasan lentur tidak mampu menahan perubahan suhu dipermukaan selain gaya-gaya dari kendaraan yang bekerja diatasnya. Penelitian ini dilakukan untuk mengkaji karakteristik perkerasan kaku yang dibuat dari beton dengan penambahan campuran bahan kimia 0,6\% Plastocrete RT06 dan 3\% Sikament-NN. Hasil ujikuat tekan beton kemudian diaplikasikan pada model numerik sistem perkerasan kaku yang dianalisis dengan perangkat lunak ABAQUS untuk mengkaji pengaruh perubahan suhu terhadap deformasi lapis perkerasan kaku. Pada model numerik ketebalan masingmasing lapisan perkerasan yaitu : $30 \mathrm{~cm}$ lapis permukaan, $20 \mathrm{~cm}$ lapis pondasi bawah, dan $50 \mathrm{~cm}$ tanah dasar. Lapis pekerasan dimodelkan sebagai material concrete, dan lap[is fondasi serta lapis tanah dasar masing-masing dimodelkan sebagai material elastic dan keruntuhan model Drucker Prager. Hasil penelitian menunjukkan bahwa nilai kuat tekan beton berkurang 13\% akibat kenaikan suhu hingga $40^{\circ} \mathrm{C}$ jika dibandingkan dengan beton normal. Defromasi plastis terjadi setelah pembeban melebihi 40,5 $\mathrm{kN}$ hingga terjadi penurunan maksimum akibat MST kendaraan sebesar $1,38 \mathrm{~mm}$ dan $1,48 \mathrm{~mm}$ masing-masing untuk beton dengan perawatan rendaman dan elevated temperature. Dengan demikian dapat dinyatakan bahwa penurunan pada lapis perkerasan kaku akibat kenaikan suhu 40oC lebih besar 7,4\%.

Kata-kata kunci: ABAQUS, chemical admixture, elevated temperature, perkerasan kaku
\end{abstract}

\section{PENDAHULUAN}

Peningkatan pertumbuhan ekonomi di D.I Yogyakarta sejalan dengan meningkatknya jumlah kendaraan yang melintas pada simpang empat di ruas jalan strategis. Pada lokasi tersebut memiliki tingkat kemacetan serta kerusakan perkerasan yang cukup tinggi khususnya pada perkerasan lentur, karena perkerasan lentur tidak mampu menahan besarnya gaya rem sehingga terjadi kerusakan sungkur dan retak slip. Oleh karena itu, perkerasan kaku lebih cocok diterapkan pada lokasi tersebut. Perkerasan kaku merupakan perkerasan yang terbuat dari beton dan beban kendaraan yang diterima akan dipikul langsung oleh plat beton, sehingga beban tidak langsung menerus menuju lapis pondasi bawah. Perkerasan kaku harus memiliki kuat tekan yang cukup baik, karena beban yang diterima dipikul langsung oleh plat beton. Oleh karena itu, nilai kuat tekan beton sangat menentukan kemampuan beton untuk menopang beban dan penurunan yang terjadi. Pencamputan bahan tambah kimia pada campuran beton dapat meningkatkan kuat tekan beton dan mengatur sifat beton sesuai yang dikehendaki. Maricar dkk. (2013) melakukan penelitian tentang pengaruh penggunaan bahan tambah platiment-VZ terhadap sifat pada beton yang memiliki kuat tekan tidak memenuhi kuat tekan rencana $\left(f_{\mathrm{cr}}{ }^{\prime}\right)$. Namun, penambahan plastiment-VZ tidak memberikan pengaruh pada umur 28 hari. Winayati dan Megasari (2017) melakukan kajian statistik terhadap pengaruh penambahan Sikament-NN terhadap karakteristik beton. Hasil analysis of variance (ANOVA) menunjukkan adanya interaksi yang kuat antara kuat tekan dengan penambahan Sikament-NN.

Ahmad dkk. (2009) menyebutkan beton akan mengalami penurunan terhadap kuat tekan dengan kenaikan temperatur. Mooy dkk. (2017) melakukan penelitian tentang pengaruh suhu curing beton terhadap kuat tekan beton yang menghasilkan kuat tekan optimal pada suhu tinggi $\left(80^{\circ} \mathrm{C}-100^{\circ} \mathrm{C}\right)$. Namun, hasil nilai kuat tekan yang sesuai hanya pada beton dengan perawatan dengan cara perendaman (Angjaya dkk., 2013). Hasil serupa diperoleh oleh Cornelis dkk. (2014) terhadap 
beton pasca bakar dengan dan tanpa perendaman untuk variasi mutu beton. Penurunan kuat tekan terjadi pada beton pasca bakar karena tidak terjadi kembali reaksi ikatan antara air dengan semen. Sutapa dkk. (2011) menyebutkan durasi perawatan pasca bakar dan tingkat pemulihan optimum beton pasca bakar terjadi pada umur 14 hari. Setelah umur tersebut beton akan mengalami penurunan seiring bertambahnya umur perendaman beton pasca bakar. Sedangkan untuk beton kinerja dan mutu tinggi, Bastami dkk. (2011) menyimpulkan bahwa tidak terjadi penurunan nilai kuat tekan beton setelah dipanaskan. Kullit dkk. (2013) menyebutkan pada perawatan elevated temperature kuat tekan dan kuat tarik belah beton yang mengalami peningkatan pada umur tiga hari, dan mengalami penurunan pada umur 28 hari. Semakin tinggi suhu perawatan yang digunakan maka nilai kuat tekan dan kuat tarik belah yang dicapai pada saat beton berumur 28 hari akan semakin rendah.

Penelitian ini bertujuan untuk mengkaji pengaruh penambahan bahan kimia dan metode perawatan elevated temperature terhadap kuat tekan beton. Karena lokasi beton ditempatkan di tempat terbuka, maka beton tersebut akan dipengaruhi temperature pada area tersebut sebesar $40^{\circ} \mathrm{C}$. Kinerja perkerasan kaku hasil desain campuran dan perawatan dimodelkan secara numerik untuk mempelajari perilaku beban dan penurunan pengaruh perubahan suhu yang diberikan terhadap kuat tekan beton yang dihasilkan dan memperoleh nilai penurunan yang terjadi karena beban dari muatan sumbu terberat pada jalan kelas 1 dengan perangkat lunak ABAQUS.

\section{METODE PENELITIAN}

\subsection{Desain Campuran Beton dan Benda Uji}

Perancangan campuran beton mengacu pada SNI 02 2834-2000 (BSN, 2000). Perancangan dilakukan untuk menentukan komposisi dan proporsi bahan penyusun beton termasuk bahan tambah. Bahan tambah yang digunakan adalah jenis chemical admixture Sikament- NN sebanyak 3\% dan Plastocrete RT06 sebanyak 0,6\% dari berat semen yang digunakan. Kegunaan Plastocrete RT06 adalah mereduksi penggunaan air pada pencampuran beton dan dapat mengontrol waktu pengerasan pada beton. Sedangkan Sikament-NN berguna sebagai bahan

Tabel 1. Kebutuhan bahan penyusun beton dengan cara perendaman dan beton elevated temperature untuk $1 \mathrm{~m}^{3}$

\begin{tabular}{llll}
\hline No & Keterangan & Nilai & Satuan \\
\hline 1 & Air & 153,68 & liter \\
2 & Semen & 499,76 & $\mathrm{~kg}$ \\
3 & Kerikil & 528,62 & $\mathrm{~kg}$ \\
4 & Pasir & 981,72 & $\mathrm{~kg}$ \\
5 & Sikament-NN 3\% & 14,99 & $\mathrm{Lt}$ \\
6 & Plastocrete RT06 0,6\% & 3,00 & $\mathrm{Lt}$ \\
\hline
\end{tabular}

Tabel 2. Hasil pengujian slump dan setting time beton

\begin{tabular}{llll}
\hline No & Uraian & $\begin{array}{l}\text { Slump } \\
(\mathrm{cm})\end{array}$ & $\begin{array}{l}\text { Setting time } \\
(\mathrm{menit})\end{array}$ \\
\hline 1 & $\begin{array}{l}\text { Beton dengan cara } \\
\text { perendaman }\end{array}$ & 12 & 140 \\
2 & $\begin{array}{l}\text { Beton dengan elevated } \\
\text { temperature }\end{array}$ & 10 & 125 \\
\hline
\end{tabular}

untuk mengurangi penggunaan air dengan jumlah yang besar serta dapat memberikan kuat tekan awal tinggi. Jumlah air yang diperlukan untuk campuran beton dikurangi hingga 25\% dari yang diperlukan. Hasil desain campuran beton untuk setiap $1 \mathrm{~m}^{3}$ disajikan pada Tabel 1.

Benda uji dibuat sebanyak 12 buah dengan cetakan berbentuk silinder yang memiliki ukuran $15 \mathrm{~cm} \times 30 \mathrm{~cm}$. Cara perawatan beton terbagi menjadi 2 jenis yaitu (1) perendaman, dan (2) perendaman yang kemudian diikuti perawatan elevated temperature dengan cara memanaskan beton pada suhu $40^{\circ} \mathrm{C}$ selama 12 jam di dalam oven.

\subsection{Uji Kuat Tekan Beton}

Pengujian kuat tekan beton dilakukan pada umur beton mencapai 7, 21 dan 28 hari. Setelah masa perawatan selesai, beton dikeluarkan dari bak rendaman dan dikeringkan selama 24 jam pada suhu ruang. Namun, untuk beton dengan perawatan elevated temperature, benda uji dimasukan ke dalam oven pada suhu $40^{\circ} \mathrm{C}$ selama 12 jam. Sebelum diuji tekan beton harus diukur terlebih dahulu dimensinya. Pengujian dilakukan pada mesin uji tekan Hung Ta HT-8391 Computer-Controlled Servo Hydraulic Concrete Compression Testing Machines dengan kapasitas mesin 2000 kN. Pembebanan dilakukan hingga beban maksimal yang dapat diterima oleh benda uji.

\subsection{Pemodelan dengan Software ABAQUS}

Loannides dkk. (2006) melakukan penelitian tentang model keretakan pada slab jalan beton dengan menggunakan ABAQUS untuk mengatasi kelemahan fungsi penyaluran yang umumnya digunakan dalam perencanaan desain perkerasan jalan. Pada penelitian ini permodelan perkerasan kaku menggunakan perangkat lunak ABAQUS ver. 6.11-2. Sistem perkerasan kaku dimodelkan berbentuk kubus dengan dimensi $1 \mathrm{~m} \times 1 \mathrm{~m}$ $\times 1 \mathrm{~m}$. (Gambar 1). Ketebalan masing-masing lapisan perkerasan yaitu : $30 \mathrm{~cm}$ lapis permukaan, $20 \mathrm{~cm}$ lapis pondasi bawah sesuai PD T-14-2003, dan $50 \mathrm{~cm}$ tanah

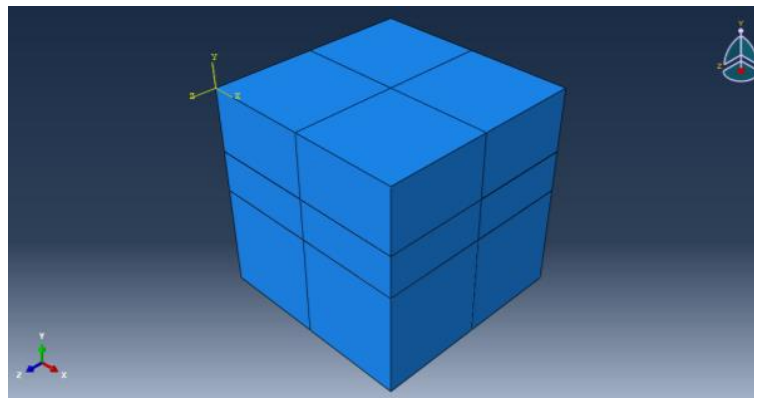

Gambar 1. Susunan lapisan dalam permodelan ABAQUS

Tabel 3 Nilai parameter material lapis tanah dasar

\begin{tabular}{ll}
\hline Parameter & Nilai \\
\hline Elastic Young's Modulus (MPa) & 58,3 \\
Poisson's Ratio & 0,3 \\
Angle of Friction $\left(^{\circ}\right)$ & 5 \\
Initial Tension & 0,05 \\
Dilation Angle $\left(^{\circ}\right)$ & 5 \\
Yield Stress (MPa) & 0,005 \\
Absolut Plastic Strain & 0 \\
\hline
\end{tabular}


dasar. Lapis perkerasan kaku dimodelkan sebagai concrete, sedangkan lapis fondasi dan lapisan tanah dasar dimodelkan dengan model elastic dan Drucker Prager. Parameter masukan yang digunakan dalam pemodelan disajikan pada Tabel 3 hingga Tabel 5.

Beban muatan sumbu terberat (MST) pada jalan kelas 1 sebesar 98,1 kN (10 ton) diletakkan di tengah potongan jalan. Analisis konvergensi penurunan dilakukan untuk menentukan jumlah elemen optimal dalam pemodelan numerik. Gambar 2 menyajikan hubungan jumlah elemen dan penurunan lapis perkerasan kaku untuk masing-masing kondisi cara perawatan beton. Dengan demikian diperoleh jumlah elemen optimal sejumlah 2744 elemen.

\section{HASIL DAN PEMBAHASAN}

\subsection{Kuat Tekan Beton}

Variasi nilai kuat tekan beton terhadap umur ditunjukkan pada Gambar 3. Kuat tekan beton dengan cara perendaman sebesar 48,3 $\mathrm{MPa}$, dan nilai modulus elastisitas beton tersebut sebesar 32,7 GPa. Sedangkan nilai kuat tekan beton dengan perawatan elevated temperature sebesar $41,9 \mathrm{MPa}$ dengan nilai modulus elastisitas yang didapat sebesar 30,4 GPa Sccara umum, cara perawatan beton dengan elevated temperature menghasilkan nilai kuat tekan yang lebih rendah sebesar $13 \%$ jika dibandingkan beton dengan perawatan

Tabel 4 Nilai parameter material agregat kasar lapis fondasi

\begin{tabular}{lc}
\hline Parameter & Nilai \\
\hline Density $\left(\mathrm{kN} / \mathrm{m}^{3}\right)$ & 17,7 \\
Elastic Young's Modulus (MPa) & 137,3 \\
Poisson's Ratio & 0,3 \\
\hline
\end{tabular}

Tabel 5 Nilai parameter material lapis perkerasan kaku

\begin{tabular}{lcc}
\hline \multirow{2}{*}{ Parameter } & \multicolumn{2}{c}{ Cara Perawatan Beton } \\
\cline { 2 - 3 } & Perendaman & $\begin{array}{c}\text { Elevated } \\
\text { Temperature }\end{array}$ \\
\hline Density $\left(\mathrm{kN} / \mathrm{m}^{3}\right)$ & 23,5 & 23,5 \\
Elastic Young's & 32,7 & 30,4 \\
Modulus $(\mathrm{GPa})$ & & \\
Poisson's Ratio & 0,2 & 0,2 \\
Dilatation Angle $\left(^{\circ}\right)$ & 30 & 30 \\
Eccentricity & 0,1 & 0,1 \\
$F_{k o} / F_{c o}$ & 1,16 & 1,16 \\
$K$ & 0,67 & 0,67 \\
Viscocity & 0 & 0 \\
\hline
\end{tabular}

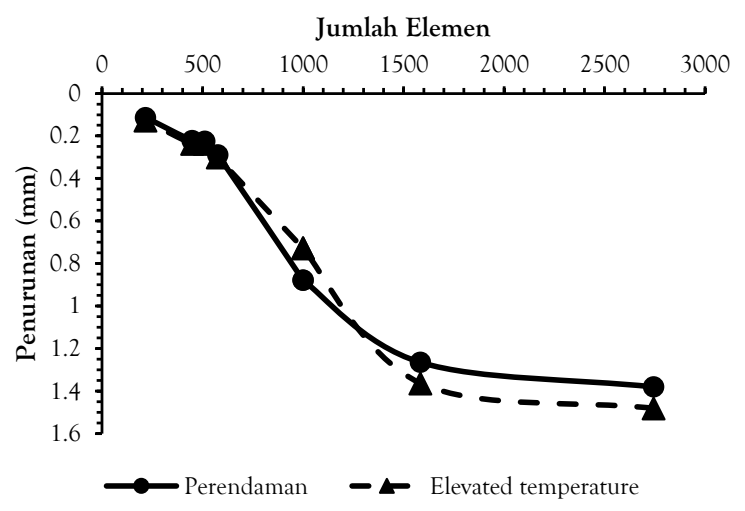

Gambar 2 Hubungan jumlah elemen dan penurunan di tengah model perkerasan kaku rendaman saja. Hasil ini seperti yang telah dikaji oleh Ahmad dkk. (2009) dan Kullit dkk. (2013). Namun pada umur awal 7 hari, beton dengan elevated temperature memiliki kuat tekan beton yang lebih tinggi 7,7\% daripada beton dengan perendaman saja. Perbedaan suhu dapat menimbulkan penyusutan dan pengurangan volume sehingga terjadi retakan pada beton. Perbedaan nilai kuat tekan beton dapat terjadi karena perbedaan nilai slump. Nilai slump beton dengan perawatan elevated temperature lebih rendah daripada nilai slump beton dengan perawatan rendaman. Kondisi ini kemungkinan kemudahan pekerjaan pencampuran (workability) menjadi rendah, sehingga campuran pada beton yang dibuat tidak homogen sehingga rongga pada beton cukup banyak dan menurunkan kuat tekan beton.

\subsection{Perilaku Beban dan Penurunan Pekerasan Kaku}

Gambar 4 menampilkan hubungan beban dan penurunan di tengah model lapis perkerasan kaku hasil pemodelan numerik untuk perawatan rendaman dan elevated temperature. Secara umum, penurunan permukaan akan semakin besar dengan bertambahnya beban yang bekerja di atas lapis perkerasan kaku. Perkerasan kaku

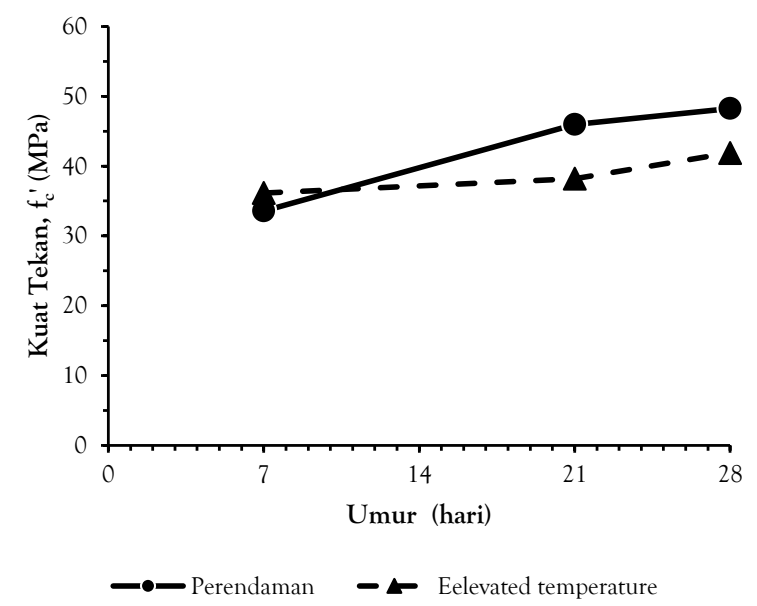

Gambar 3 Grafik hubungan antara umur beton dengan kuat tekan rata-rata beton

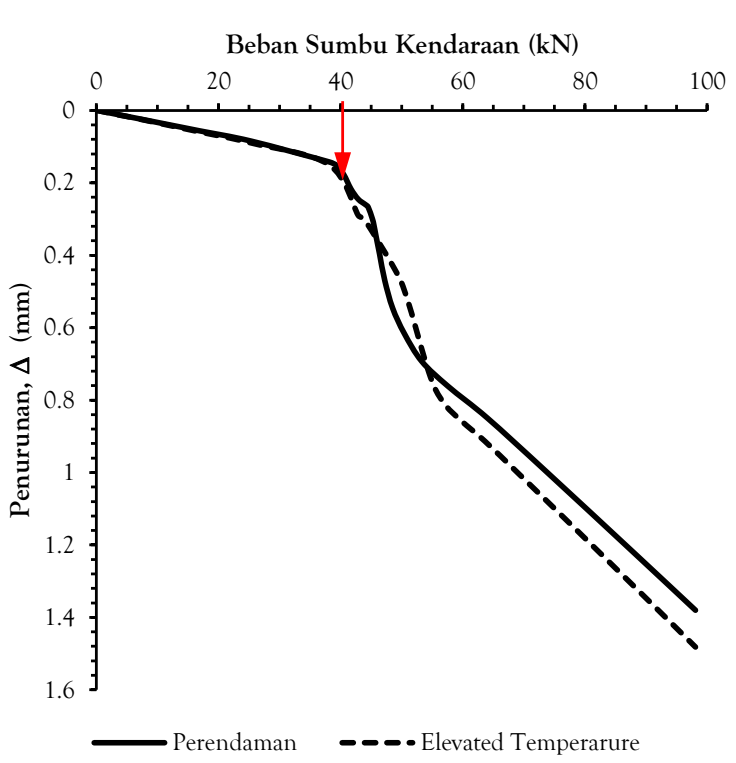

Gambar 4 Hubngan beban dan penurunan di tengah model lapis perkerasan kaku hasil pemodelan numerik 
masih berperilaku elastis-linier hingga pembebanan mencapai 40,5 kN (lihat tanda panah pada Gambar 4) baik dengan perawaran rendaman dan elevated temperature. Pada beban ini dapat ditentukan penurunan elastis sebesar 0,15 mm. Defromasi plastis terjadi setelah pembeban melebihi 40,5 kN. Penurunan maksimum akibat beban terberat sumbu kendaraan adalah $1,38 \mathrm{~mm}$ dan 1,48 mm masing-masing untuk beton dengan perawatan rendaman dan elevated temperature. Dengan demikian dapat dinyatakan bahwa penurunan pada lapis
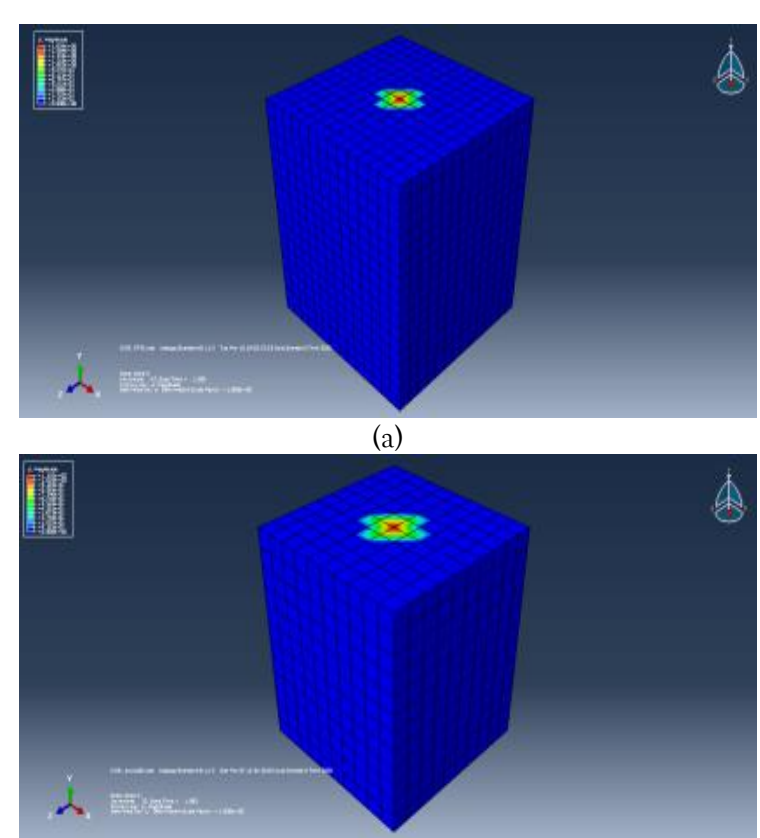

(b)

Gambar 5 Pola sebaran deformasi di permukaan lapis perkerasan kaku akibat beban sumbu kendaraan (a) beton dengan perawatan rendaman, (b) beton dengan perawatan elevated temperature.

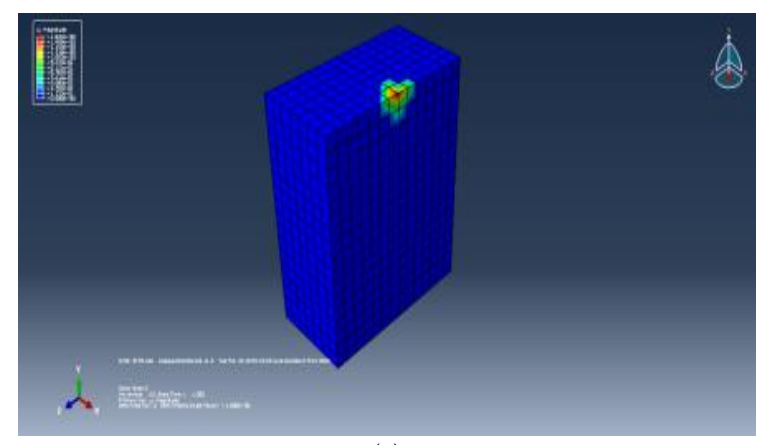

(a)

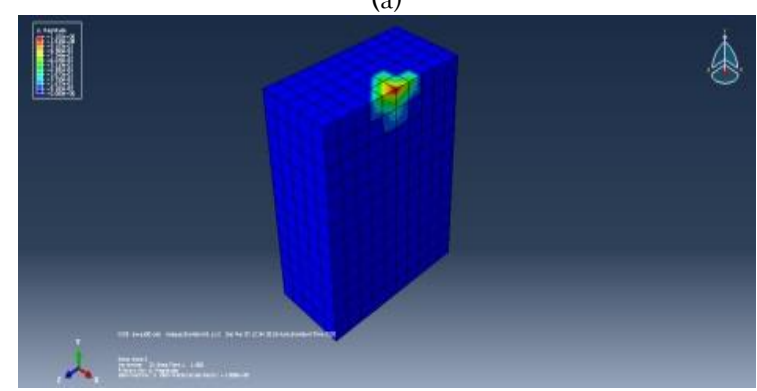

(b)

Gambar 6. Pola sebaran deformasi pada lapisan-lapisan perkerasan kaku akibat beban sumbu kendaraan (a) beton dengan perawatan rendaman, (b) beton dengan perawatan elevated temperature. perkerasan kaku akibat kenaikan suhu $40^{\circ} \mathrm{C}$ lebih besar $7,4 \%$.

Gambar 5 memberikan ilustrasi pola defomasi di permukaan lapis perkerasan kaku untuk kondisi dengan perawatan rendaman dan elevated temperature. Untuk beton dengan perawatan rendaman memiliki sebaran deformasi yang lebih terpusat di beban MST (Gambar 5a). Sedangkan sebaran deformasi karena elevated temperature lebih luas (Gambar 5b). Demkian pula sebaran deformasi akibat elevated temperature lebih dalam (Gambar 6b) jika dibandingkan dengan perawatan rendaman saja (Gambar 6a). Apabila kerusakan permukaan kalan dinilai dari besarnya penurunan dan sebaran deformasi akibat MST yang bekerja, maka lapis perkerasan kaku memiliki potensi kerusakan yang lebih besar akibat pengaruh kenaikan suhu di permukaan pekerasan jalan.

\section{KESIMPULAN}

Berdasarkan hasil penelitian dan pembahasan yang telah diuraikan maka dapat dituliskan kesimpulan sebagai berikut :

1. Nilai kuat tekan beton dengan peendaman lebih besar 13,\% dari pada beton dengan perawatan elevated temperature. Nilai kuat tekan rata-rata pada umur 28 untuk beton perendaman yaitu 48,3 $\mathrm{MPa}$ dan 41,9 MPa untuk beton dengan elevated temperature. Namun pada umur awal 7 hari, beton dengan elevated temperature memiliki kuat tekan beton yang lebih tinggi 7,7\% daripada beton dengan perendaman saja.

2. Perkerasan kaku masih berperilaku elastis-linier hingga pembebanan mencapai 40,5 kN (4,1 ton) baik dengan perawatan rendaman dan elevated temperature. Defromasi plastis terjadi setelah pembeban melebihi $40,5 \mathrm{kN}$ hingga terjadi penurunan maksimum akibat MST kendaraan sebesar $1,38 \mathrm{~mm}$ dan $1,48 \mathrm{~mm}$ masing-masing untuk beton dengan perawatan rendaman dan elevated temperature. Dengan demikian dapat dinyatakan bahwa penurunan pada lapis perkerasan kaku akibat kenaikan suhu $40^{\circ} \mathrm{C}$ lebih besar 7,4\%.

\section{Daftar Pustaka}

Ahmad, I. A., Taufieq, N. A. S., dan Aras, A. H., 2009, Analisis Pengaruh Temperatur Terhadap Kuat Tekan Beton, Jurnal Teknik Sipil, 16 (2), 67-69.

Angjaya, N., Kurmaat, E. J., Tanudjaja, W. H., 2013, Perbandingan Kuat Tekan Antara Beton Dengan Perawatan Pada Elevated Temperature dan Perawatan Dengan Perendaman Serta Tanpa Perendaman, Jurnal Sipil Statik, 1 (3), 153-158

Bastami, M., Khiabani, A., C., Baghbadrani, M., dan Kordi, M., 2011, Performance of High Strength Concrete at Elevated temperatures, Scientia Iranica A, 18 (5), 1028 . 1036.

BSN, 2000, SNI 03-2834-2000 Tata cara pembuatan rencana campuran beton normal, Badan Standardisasi Nasional, Jakarta 
Adly \& Fatimah / Buletin Teknik Sipil 1:1 (2017) 19-23

Cornelis, R., Hunggurami, E., dan Tokang, N. Y., 2014, Kajian Kuat Tekan Beton Pasca Bakar Dengan dan Tanpa Perendaman Berdasarkan Variasi Mutu Beton, Jurnal Teknik Sipil, 3 (2), 161 - 172.

Kullit, V. I., Wallah, S. E., Tambato, W. J., Pandaleke, R., 2013, Pengaruh Variasi Suhu Pada Perawatan Elevated temperature Terhadap Kuat Tekan dan Kuat Tarik Belah Beton, Jurnal Sipil Statik 1 (7), 473-478.

Loannides, A. M., Peng, J., dan Jr., J. R. S., 2006, ABAQUS Model for PCC Slab Cracking, International Journal of Pavement Engineering 7 (4), 311-321.

Maricar, S., Tatong, B., dan Hasan, H., 2013, Pengaruh Bahan Tambah Plastiment-VZ Terhadap Sifat Beton, Majalah Ilmiah Mektek 15 (1), 39-50.
Mooy, M., Simatupang, P. H., dan Frans, J. H., 2017, Pengaruh Suhu Curing Beton Terhadap Kuat Tekan Beton, Jurnal Teknik Sipil 4 (1), 47-60.

Pd t 14-2003 -Pedoman Perencanaan Perkerasan Jalan Beton Semen, Departemen Permukiman Dan Prasarana Wilayah, Jakarta

Sutapa, A. A. G., Saputra, I. G. N. O., dan Mataram, K., 2011, Pemulihan Kekuatan Tarik Belah Beton Dengan Variasi Durasi Perawatan Pasca Bakar, Jurnal Ilmiah Teknik Sipil 15 (2), 205-215.

Winayati, dan Megasari, S. W., 2017, Analisis Pengaruh Penambahan Sikament-NN Terhadap Karakteristik Beton, Jurnal Teknik Sipil 3 (2), 117-128. 